\title{
STOP THE DRIVE OF EMIGRATION TOWARDS NEW GENOCIDE
}

\begin{abstract}
This paper discusses the ways for reducing the modern huge wave of emigration from Armenia that became a serious threat to national security. The author suggests introducing a temporary law of emigration quotas for immediately bringing down the emigration rates to the medium international level. USA and other developed countries regulate their immigration problems just with the help of immigration quotas. This paper also suggests discussing perspectives of a special law, according to which a family would have the right of emigration from Armenia, if all grown up members of the family have university or technical college diploma or a craft certificate. This law could help Armenian emigrant families to get decent life abroad and keep strong ties with motherland thus avoiding the danger of assimilation, the nowadays "white genocide".
\end{abstract}

Keywords: mass emigration, white genocide, preventive measures, temporary laws, emigration quotas, social security of emigrant families, ties with motherland.

One of the most important results of public events in remembrance of Armenian genocide centenary was the realization of the fact that the present tendency of mass emigration from Republic of Armenia is comparable to the danger for the very existence of Armenian nation caused in the past by Ottoman Turks. Moreover, the present huge dimension of emigration from Armenia is rightly evaluated as real danger to the national security of the Republic of Armenia. "In the entire period of existence of the Third Republic the problem of emigration was assessed as very actual and in recent years the emigration got frightening dimensions which grew to the extent of a real danger for national security", is stated in the program of Armenian Revolutionary Federation "We shall live in our country" (ARF 2013).

At present emigration is not a specific Armenian phenomenon since it is "the native child" of globalization. The latter is usually interpreted as the process of formation of the world's unified economic market (Sahakyan 2009). Economic globalization requires international division of labor. This circumstance, in particular, is underlined by V. Kirakosyan: "Globalization is more than formation of global economy. The latter presumes uniting countries in the international division of labor, in world financial system" (Kirakosyan 2007: 35).

Countries that are in the same phase of economic development as Armenia are defined by international division of labor to serve a source of manpower that inevitably starts emigration waves of laborers and their families to more developed countries that require masses of manpower. Thus, the present process of globalization unavoidably becomes an insurmountable factor of unprecedented mass emigration from Armenia and many other underdeveloped countries.

It is no secret that globalization is kept in motion by means, influence and direct dictate of international financial and technological corporations. A. Marjanyan points out that under the pressure of several factors of globalization the very foundations of national states are shaken down. Classical con- 
cepts of "national economy", "national security" and related notions became diffused and "unfashionable"(Marjanyan 2011: 31). Well known financier G. Soros mentioned: "The global capitalism puts countries of the world in non-equal conditions. The precipice between the rich and poor gets bigger. The system that does not give any hope and does not help losers, incites them to make nonconstructive steps, dictated by hopelessness, and is risking to brake the system from inside (Soros 2001)."

The social-economical experience of the last two centuries makes it clear that in the society where the highest values are money and wealth, just the financial capital becomes the ruler of the country. One can't establish social justice and descent life conditions for people in the society where the highest values are money and wealth (Gasparyan, Djidjian 2015).

The power and dictate of the wealthiest social elite is the deepest and most basic cause that has demoralized the entire people of this country and has decreased patriotic feelings of Armenian young generation. Just by this reason the young generation of this country becomes used to the idea that it is quite a normal behavior to leave motherland and immigrate to foreign countries for a better life.

Thus it becomes quite clear that the present problem of mass emigration from Armenia could be radically solved when the entire society puts all its energy and activity to form with the help of family and school education a deep and truly patriotic belief that the highest values of life are freedom of his people and independence of this country but not money, wealth or bodily pleasures.

The specific difficulty for solving the mass emigration problem is conditioned by the circumstance that all political parties in Armenia and Diaspora realize the necessity for immediately and radically decreasing the rate of mass emigration from Armenia, yet none of them succeeded to suggest a convincing solution to the problem.
Authorities of this country in their government of AR 2011 program for migration regulation present a complex study of the situation. Yet official interpretations try to convince that there is nothing extraordinary in the present rate of emigration from Armenia. It is assessed in the official forecast that "in the next 5 to 10 years this country might leave around 300 thousand people". According to the opinion of the organization Analiticon, the representatives of the government admit that they are worried by the mass emigration, but do not think that its rate is dangerous and presumably mass media data are rather overstated. But if we consider the upper level of the official mass emigration forecast - 300 thousand people in five years - then in coming 20 years around one million people should emigrate from Armenia. If the upper level of the official forecast comes true, then by 2030 the population of Armenia may become less than half of the 4 million population of Soviet Armenia in 1991. Considering the outlined situation, one may recall the bitter words of the Armenia's great patriot Charles Aznavour: "An inner genocide is taking place in my country".

The political opposition parties of this country, by exception of ARF, unanimously declare that coming to power they would solve all the problems of the RA, including the problem of mass emigration. Yet they do not suggest any immediate solution to the problem. Moreover, some opposition writers obviously driven by the psychology of political struggle suggest a kind of justification for emigrants from Armenia following "free-market democracy" line argumentation. Each citizen, insist radical libertarians, has the right to demand from the government of his country to fulfill its high-priority obligation - to provide him descent salary and descent life conditions. And if the government appears unable to carry out its high-priority obligation and there is no real perspective for political power change in the country then the citizen, in full accord with freemarket ideology, has full moral right to leave this 
country. In short, if one can't change government then he is free to emigrate from his country. Yet it's easy to see that this "democratic" line of judgment is a certain kind implicit argumentation in favor of emigration. But the proponents of this type "freemarket democracy" argumentation should realize that after another change of political power another group of people would emigrate from the country this time already unhappy with the new political leadership.

One should mention that beside the government of AR 2011 program for migration regulation there are another two serious investigations - the above mentioned ARF 2013 strategic program for prevention of mass emigration from Armenia and the Qololyan commission for emigration study 2013 Report. All three documents are serious and valuable investigations undertaken scientifically and profoundly. They pursue the same goal: to reveal the system of causes and negative factors of mass emigration from Armenia and to find out the ways for liquidation or/and limitation of these negative factors and causes.

What are the conclusions of these three fundamental investigations in regard of the causes of mass emigration from Armenia? Concerning this question I would like to mention the 2014 sociological inquiry carried on by the prominent sociologist Aharon Adibekyan Centre "Sociometry" with the task to reveal the tendencies of emigration in different regions of RA. "Sociometry" Centre inquiry established the main cause of the mass emigration from Armenia, which writers on the subject have pointed out earlier, namely, the economic hardship of the significant part of the population.

The government of AR 2011 program for migration regulation, though not using the term massemigration, actually accepts its significance: "today the government of the Republic of Armenia considers the task of effective solution of the migration regulation problem as one of the main challenges for the state". According to this Program, the government of the Republic of Armenia, starting from the year 2000, has taken a number of strategic decisions in regard of migration process regulation which declare the unlawful and unregulated emigration, especially that of white collar specialists of education, science and culture, as real danger for national security and pay serious attention to processes of migration in their relation and influence to social-economic problems of this country. According to the above mentioned government decisions all the instruments of the state policy making should be put into action for preventing mass emigration from Armenia.

Unfortunately the authors of the government Program for migration regulation do not pinpoint the concrete negative main factors causing mass migration and do not suggest ways and mechanisms of their regulation. The Program rather gives the general outline of the problems and mentions those strategic decisions of the government of RA that contain general political measures and arrangements for the regulation of the entire scope of the revealed problems. In fact, the government Program for emigration regulation is just another strategic document for activation of the previously accepted strategic documents in regard of massive emigration regulation. Unfortunately the government Program does not suggest immediate and urgent measures for prevention and regulation of the present time mass emigration from Armenia.

This kind of complex and all-embracing approach calls on to undertake solutions of such a deep and multilateral political and social-economic problems for which this country has no time resource because of the huge dimension of the present time mass emigration. Indeed, all investigators of the present situation with emigration from Armenia point out that one of the main causes of the mass emigration is that of economic hardship. On the other hand, the Republic of Armenia is at present in economic blockade and in acute conflict over Nagorny Karabach that caused war with Azer- 
baijan and nowadays is in the state of smoldering temporary truce. In fact, the economics of Armenia being rather oligarchic than free market type needs decades for its radical reforming and improvement.

Last but not the least, undertaking the solution of the problem of regulation of mass emigration one must take into account that the huge dimension of the emigration has created in the RA an emergency situation from the viewpoint of national security. In general, the regulation of an emergency situation requires urgent measures. It is necessary to find out such emergency ways for immediately decreasing the present emigration from RA which could afford bringing it down in a couple of years to that of the medium emigration rate from neighboring post-soviet republics.

As such an urgent measure we suggest the following: to take a government decision for quotas of emigration from the RA that could bring down the emigration rate from this country to the medium value of emigration from neighboring post-soviet republics. We would like to underline that USA and several other states regulate the problems of immigration to their countries just using the instrument of immigration quotas. By using our suggestion the government of RA and the patriots of this country would gain time for more profound solution of the problem of mass emigration.

\section{REFERENCES}

ARF program. (2013). "We shall live in our country". http://www.arfd.info/=12435

Gasparyan, Yu., Djidjian, R. (2015).Azgayin anvtangut'yan sociologia (Sociology of $\mathrm{Na}$ tional Security). Yerevan: Limush.

Kirakosyan, V.L. (2007). Hamashxarhayin tntesut'yany' $\mathrm{HH}$ integrman ughinery'(The Ways of Integrating the Economics of RA into the World Economy). Yerevan: heghinakayin hratarakut'yun.
From the viewpoint of the national security in general, and taking into account the huge rate of mass emigration from Armenia in particular, we find it useful to have a special law "On the social future of emigrating families". This law should require from emigrating families that each grown up member of the family had to have university or technical college diploma or a craft certificate. This law, along with the function of regulating the emigration rate, would have also an important social function. Namely if a young member of a given family does not have university or technical college diploma or a useful craft certificate, then he would land in the lowest social stratum of small salary workers of the country of emigration. This circumstance would have negative impact on the life level of the young generation as well as on the general social-economic situation in the newly forming Armenian Diaspora.

The educational-professional law that we suggest to discuss could have a special significance for families that are going to immigrate to Russian Federation because our universities are yet capable to provide high level Russian for young Armenian postgraduates. Craft certificates could be still useful in Russia since Armenian laborers, especially country side builders have good reputation all over Russian population.

Marjanyan, A. (2011). Azgayin anvtangut'yuny' global ashxarhaqaghaqakan popoxut'yunneri darashrjanum: 21-rd dar (National Security in the Age of Geopolitical Changes). 2011, No 1, p. 31.

Sahakyan, Sh. (2009).Marqet'ingy' global tntesut'yunum(Marketing in the Global Economy). Yerevan: Tntesaget.

Soros, G. (2001). Otkrytoe obshchestvo. Reformiruya global'nyi kapitalizm (Open Society. Reforming Global Capitalism). Moskva: fondPodderzhki kul'tury, obrazovaniya i novykh informatsionnykh tekhnologii. 